\title{
REORIENTING SUFISM: HAMKA AND ISLAMIC MYSTICISM IN THE MALAY WORLD
}

\section{Khairudin Aljunied}

This article examines the ideas of a prominent Southeast Asian thinker on Sufism in the Malay World. Haji Abdul Malik bin Abdul Karim Amrullah (1908-81), better known by his penname "Hamka," is still regarded today as one the most influential Muslim public figures in Indonesia, Malaysia, Brunei, and Singapore. He wrote more than a hundred books that covered a wide variety of topics, including Islamic philosophy, theology, history, jurisprudence, ethics, literature, and culture. More than three decades after his death, his books are still read and referred to by many Muslim scholars across the Southeast Asian region. Many of his writings are assigned as essential texts for university courses in Malaysia and Indonesia, and his writings on Sufism still attract a wide readership. ${ }^{1}$

Born in Minangkabau, in Sumatra, in the early twentieth century, Hamka hailed from a family of scholars and reformers who held different views about Sufism. His great-grandfather and grandfather were both proponents of Sufi practices and subscribed to the Naqshbandiyyah Sufi order, which had a strong following in island Sumatra as well as in other parts of the Malay World. By comparison, Hamka's father, Abdul Karim Amrullah, was an ardent opponent of Sufistic tendencies and one of the

Khairudin Aljunied is an Associate Professor at the Faculty of Arts and Social Sciences, National University of Singapore.

1 To be sure, the supply of postgraduate theses and critical studies on Hamka alone deserves a bibliography of its own. A few years after Hamka's death, a French scholar put together what is now a rather dated, yet still indispensable bibliography of his publications and works about him. See: Gerard Moussay, "Une grande figure de l'Islam indonesien: Buya Hamka," Archipel 32, (1986): 87-111. 
leading proponents of Islamic modernism in modern Indonesia. Together with Mohammad Djamil Djambek, Sheikh Abdullah Ahmad, and Sheikh Thaib Umar, all of whom spent many years studying in Mecca, Abdul Karim Amrullah formed a formidable anti-Sufi faction that invited strong reactions from Sumatra's traditionalist Muslim leaders. ${ }^{2}$ As one of the leaders of the Muhammadiyah reformist movement in Indonesia since the 1930s, Hamka witnessed the ebb and flow of Sufism in Indonesia and was in the prime of his life when many syncretic mystical movements began to take hold in the hearts of Muslims across the Malay World in the 1970s. ${ }^{3}$ It was the conflicts among these seemingly opposing groups within his family and changes in societal attitudes toward Islamic mysticism that drove Hamka to construct and write about his own visions for Sufism. Hamka realized that, if left to fester, the differences between Sufis and anti-Sufis could tear apart the Malay World's Muslim community, leaving it susceptible to other powers and influences that would threaten the faith of the Muslims. ${ }^{4}$

In addition to the conflicts that were raging in his homeland, Hamka's wide reading of the works of Sufis shaped his thinking about that mystical school of thought within Islam. He was exposed to an extensive collection of Arabic works, both in his own home and in the publishing houses where he worked as a journalist for most of his adult life. Among the books that left a deep impression on him were those that touched on Sufism as well as other cognate topics, such as Islamic history, philosophy, theology, and literature. A Muslim thinker who had a great influence on Hamka's views about Sufism was Ibn Qayyim (1291-1350), who, in turn, championed the works of his reformist teacher, Ibn Taimiyyah (1263-1328). Both scholars, according to Hamka, advocated a balanced approach toward Sufism, promoting neither an exultant adulation nor a deep hostility of it. ${ }^{5}$

In the following pages I develop the argument that, while Hamka agreed that corrupted versions of Sufism could do much harm to Islam and Muslims, he was firmly opposed to hardline approaches to Sufi thought, doctrines, and followers. Hamka saw how his contemporaries' harshness and severity toward Sufism had earned them a long list of epithets from reformists, including kafir (disbeliever), sesat lagi menyesatkan (led astray and leading others astray), mu'zilah (extreme rationalist), and zindiq (one who does not hold strong to Islamic precepts). He regarded these bitter attacks on Sufism as an exercise in futility. Their vitriolic criticisms of Sufism had placed the very people whom they were seeking to reform on a defensive path of resistance. ${ }^{6}$ Rather than join with the anti-Sufi reformists and modernists on one side of the religious divide, or with the Sufis and traditionalists on the opposing side, Hamka sought to reconcile them. Hamka wanted to build a conduit between the Sufis and the anti-Sufis, a conduit based on what Hamka termed "reorienting Sufism"

\footnotetext{
${ }^{2}$ Zaim Rais, Against Islamic Modernism: The Minangkabau Traditionalists' Responses to the Modernist Movement (Jakarta: Logos Wacana Ilmu, 2001), 32.

${ }^{3}$ Martin van Bruinessen, "The Origins and Development of Sufi Orders (Tarekat) in Southeast Asia," Studia Islamika - Indonesian Journal for Islamic Studies 1, no. 1 (1994): 13.

${ }^{4}$ Hamka, Said Djamaluddin Al-Afghany: Pelopor Kebangkitan Muslimin (Djakarta: Penerbit Bulan Bintang, 1970), 174.

${ }^{5}$ See: Hamka, Tasauf: Perkembangan dan Pemumiannya (Jakarta: Pustaka Panjimas, 1983), 204, 240; and Hamka, Kenang-Kenangan Hidup (Kuala Lumpur: Pustaka Dini, 2009), 17583.

${ }^{6}$ Hamka, Ayahku (Jakarta: Jayamurni, 1950), 105-6.
} 
(mengembalikan dan memurnikan tasauf). He believed that it could be accomplished through the questioning of inherited understandings and manifestations of Islamic mysticism in history and through discursive means.

There are several distinct but closely interrelated aspects of Hamka's effort to reorient Sufism. First, he sought to clarify the origins of Sufism, emphasizing its historical role as a fundamental aspect of Islam by linking it to the time of Prophet Muhammad. Sufism, from such a vantage point, was not an innovation of later generations. It began with the Prophet himself, and ought to be conceptualized as part of the Prophetic tradition (versus being treated as a posterior development). Linked to this historical perspective was his delineation, in clear terms, of what Sufism was and was not. He outlined the actual objectives of Sufism and explained, via philosophical and cultural currents, those un-Islamic or "foreign" elements that have been accepted into the tradition. At the same time, Hamka documented the positive contributions of Sufism. He showed the multifarious achievements of Sufis on the global venture of Islam and the multiple roles that they played in Muslim societies. Hamka's third approach in reorienting Sufism was to encourage Sufis to regain their historical dynamism by reinterpreting some key concepts in Sufi cosmology and ridding Sufism of superstition and irrationality. Hamka urged Sufis, and, by implication, ordinary Muslims in the Malay World, to adapt to the demands of the modern world, admonishing them and their interlocutors to focus on and emphasize the positive aspects of spirituality in the lives of Muslims. "Indeed," Hamka emphasizes,

true Sufism does not enjoin the fleeing of man from the realities of life. True Sufism serves as a guide for one to confront the challenges of life. True Sufism does not encourage the flight to forests other than to immerse in the heart of society. Because the society needs spiritual guidance. ${ }^{7}$

Hamka's intellectual position, straddling and balancing between opposing views and proclivities, has earned him hybrid descriptions, such as a "pioneer of neo-Sufism in Indonesia," "a mystical teacher," "a Sufi without tariqah," "a cryptic Sufi," "Salafist Sufi," "Sufi sederhana" (moderate Sufi) and "Sufi berakal" (rational Sufi), and a contributor "to the process of rehabilitation for the mystical path in Indonesian Islam." ${ }^{8}$ These descriptions confirm the place that Hamka has carved for himself in popularizing modernized notions of Sufism. And yet, preceding studies on Hamka and Sufism suffer from one weakness, that is, they limit the reach of Hamka's visions of Sufism to the Indonesian context per se, and exclude the modern Malay World (which includes Singapore, Malaysia, Brunei, Indonesia, South Thailand, and South Philippines).

A close reading of Hamka's works shows that he was not concerned only with the well-being of Indonesians or Indonesian Sufism, but was seeking to reorient Sufism as

\footnotetext{
${ }^{7}$ Hamka, Pandangan Hidup Muslim (Kota Bahru: Pustaka Aman, 1967), 56.

${ }^{8}$ See: Karel Steenbrink, "Hamka (1908-1981): A Mystical Teacher as Political Leader of Islam in Indonesia” (unpublished paper, IAIN Syarif Hidayatullah, Indonesia, 1982); Nurcholish Madjid, Dialog Keterbukaan: Artikulasi Nilai Islam dalam Wacana Sosial Politik Kontemporer (Jakarta: Paramadina, 1998), 320; Azyumardi Azra, Menuju Masyarakat Madani: Gagasan, Fakta dan Tantangan (Bandung: Remaja Rosadakarya, 1999), 103; Peter Riddell, Islam and the Malay-Indonesian World: Transmission and Responses (Honolulu: University of Hawai'i Press, 2001), 264; and Julia D. Howell, "Indonesia's Salafist Sufis," Modern Asian Studies 44, 5 (2010): 1032.
} 
it was practiced by Malays in general-a group that constitutes one of the largest Muslim populations in the world. ${ }^{9}$ For example, in his nine-hundred-page book on the history of Muslim peoples, Sejarah Umat Islam, part of which was first published in Singapore in 1950, Hamka registered the dialogues among local Muslim scholars in the Malay World regarding hal ilmu tasawwuf (developments in the knowledge of Sufism), and pointed to the need for Sufism to be analyzed from the perspective of connections and interactions within the region and the Muslim world in general. ${ }^{10}$ Due to his broad approach to issues affecting the Malays, as early as the 1930s, Hamka's writings had begun circulating outside Indonesia into various parts of the Malay World, particularly in the Malay Peninsula and Singapore. Pedoman Masyarakat, a magazine that Hamka edited and contributed actively to in the years between 1936 and 1942 (on the eve of the Second World War in Asia), was read by students at the Sultan Idris Training College (SITC) in Perak. ${ }^{11}$

More important, Hamka sought to transcend ideological boundaries between reformists and modernists, on the one hand, and Sufis, on the other. He achieved this in a few ways. First, he defined Sufism differently than did other Muslim scholars. Second, he outlined the parameters of Sufism in ways that unsettled the conceptions of dissenters and defenders of Sufism, and reasserted the place of Sufism in modern society. Above all, Hamka showed that Sufism has been and can still be a constructive force in the remaking of Muslim societies in the Malay World. In developing such notions about Sufism, Hamka positioned himself between Sufi and anti-Sufi thoughts of his time, problematizing both positions and articulating his own visions of what Sufism is and ought to be. It is for this reason that Hamka's ideas on Sufism are worthy of study and may be compared to attempts by Muslim thinkers around the world who sought to close the ideological gulf between Sufis and anti-Sufis.

\section{On the Origins of Sufism}

When did Sufism begin? There have been protracted debates among scholars over this question. Hamka was well acquainted with various interpretations when he began writing about Sufism in the 1930s. Hamka's method of establishing the true origins of Sufism was to use what Émile Durkheim has termed "the argument by elimination."12 This involved Hamka's systematic rejection of all possible alternative explanations to establish his own rendering of how, when, and why Sufism came into being. Hamka directed his initial criticisms against the European Orientalists, and, in consequence, also against the Muslim reformists and modernists who claimed that Sufism was a byproduct of the Persian, Hindu, Christian, and Greek philosophical traditions rather than a product of Islam itself. Hamka regarded Max Horten (1874-1945), G. J. E. Blochet (1870-1937), Louis Massignon (1883-1962), Ignác Goldziher (1850-1921), De Lacy O'Leary (1872-1957), Theodor Nöldeke (1836-1930), R. A. Nicholson

\footnotetext{
9 "Mapping the Global Muslim Population," http://www.pewforum.org/2009/10/07/mapping-the-globalmuslim-population/, accessed on February 17, 2015.

${ }^{10}$ Hamka, Sejarah Umat Islam (Singapura: Pustaka Nasional, 1994), 729.

" Byungkuk Soh, "Ideals without Heat: Indonesia Raya and the Struggle for Independence in Malaya, 1920-1948," Wacana: Jumal Ilmu Pengetahuan Budaya 7, 1 (2005): 5.

12 Émile Durkheim, Rules of Sociological Method (New York: The Free Press, 1982), 78.
} 
(1868-1945), and Edward Browne (1862-1926) as some of the scholars who had popularized this interpretation to the point that Muslims themselves had accepted it as authoritative. ${ }^{13}$

Hamka eliminates the Orientalists' postulations systematically. The Orientalists had committed a few fallacies that led to spurious conclusions about Sufism. They were overly reliant on the writings of selected Muslim scholars who drew connections between Sufism and other spiritual and philosophical traditions. Hamka gives the example of the theory of the Hindu origins of Sufism. Proponents of this theory were influenced by the writings of Al-Biruni, who compared Indian and Islamic spiritual practices in his ethnographic work. From this, the Orientalists concluded that Sufism must have originated from Hinduism. But Al-Biruni, Hamka disputes, was writing in the eleventh century, while Sufism existed many hundreds of years prior to that era. Moreover, there is no clear-cut evidence pointing to the use of Sanskrit or any Indian loanwords whatsoever within many early Sufistic writings and sayings. ${ }^{14}$ Arguing in the same vein as Hamka, Francesco Alfonso Leccese states that the Orientalists' tracing of the origins of Sufism back to Hindu monasticism and asceticism was borne out of their perception of Sufism as a "universal 'spiritual' doctrine." That is to say, the Orientalists negated the predominant assumption among many Muslim scholars that Sufism is a distinct form of spirituality that originated from the Islamic tradition and not elsewhere. ${ }^{15}$

The second fallacious theory assumes that Sufism emerged out of a creative borrowing from other preceding beliefs. This strand of reasoning was premised on the assumption that Muslims were too "primitive" to be able to devise their own spiritual philosophies. ${ }^{16}$ Hamka faults the Orientalists for asserting that Sufism must have drawn its inspiration from the mystical beliefs that were already present in Christianity, a religion that was popular among a large segment of the Arabs before the coming of Prophet Muhammad. To counter this, Hamka stressed that the early Muslims acknowledged both Christians and Jews as "people of the book" who were given revelations by the One True God. However, spiritual practices within Islam differed from these religions, and Sufis relied upon the Qur'an and the Hadith rather than Christian or Jewish texts. Hamka further problematizes the Orientalists' hypothesis that the wearing of wool by Sufis provides clear evidence of Sufism's Christian allegiances. To Hamka, this supposition is untenable because woolen clothes were worn by most desert Arabs in the classical period. This has little to do with Sufis treading the paths of the Christian mystics. ${ }^{17}$ Hamka's reasoning predated Nile Green's recent assertion that "even if Muslim ascetics did copy the style of Christian ascetics, this does not necessarily point toward a Christian 'origin' for the

${ }^{13}$ Hamka, Tasauf: Perkembangan dan Pemumiannya (Jakarta: Pustaka Panjimas, 1983), 48.

14 Ibid., 56.

${ }^{15}$ Francesco Alfonso Leccese, "Islam, Sufism, and the Postmodern in the Religious Melting Pot," in Routledge Handbook of Islam in the West, ed. Roberto Tottoli (London: Routledge, 2015), 441.

${ }^{16}$ For a discussion of this, see: See Charles Le Gai Eaton, Islam and the Destiny of Man (New York: State University of New York, 1985), 39.

17 Hamka, Tasauf: Perkembangan dan Pemurniannya, $60-61$. 
Sufis, because far from being the direct heirs of the ascetics, the Sufis may be better understood as their rivals and critics." 18

Finally, Hamka criticized the Orientalist theory that Sufism developed from the fusion of Muslim and Greek thought. He conceded that Greek thinkers such as Socrates, Plato, and Aristotle did have a defining impact on Muslim thinkers during the Umayyad period and thereafter. But the influence of Hellenism on Muslim thinkers was not evident during the time of the Prophet, nor could the origins of Sufism be attributed to encounters between early Muslims and Greek thought simply because the influence of Greece on the Arabs was minimal during the time of the Prophet. Even though Muslim thinkers after the time of the Prophet incorporated Greek ideas into their writings, they used these ideas "merely as tools [bahan] and not as ends in themselves. They [the Muslim thinkers] stood within their own philosophical tradition under the ambit of Islam."19

Hamka felt that the problem of bias undergirded all these Orientalist fallacies. Orientalists allowed their prejudices against Islam to color their analyses of Islamic history, making it seem that the origin of Sufism was not to be found within Islam, but, rather, from factors that were external to the religion itself. ${ }^{20}$ This strong contention that Hamka made about the Orientalists' misrepresentations of Sufism has been partially validated by recent studies on the topic. As Linda Sijbrand has pointed out, even the most ardent admirers of the Sufis, such as Louis Massignon, "understood Sufism through the lens of Christianity."21

Then again, the problem of bias could well be applied to Hamka's own take on Orientalism. While scholars such as Sijbrand acknowledge the Orientalists' contributions in correcting some Western academics' mistaken ideas about Sufism, Hamka's appraisal of Orientalism tended to be reductionist, essentialist, and, at times, disparaging. He gives his readers the impression that there is really nothing to be gained from Orientalist scholarship on the subject of Sufism. Such radical antiOrientalism was characteristic of many Muslim writers in the Malay World during Hamka's era-the age of decolonization, from the 1940s into the 1980s-when these Muslim writers cast Western scholarship on Islam in negative terms as a means to vindicate their own reading of Muslim intellectual legacies and contributions in history. ${ }^{22}$ The fact remains that many leading Orientalists, too, doubted the theory that Sufism originated from non-Islamic sources. As early as 1947, the French Orientalist René Guénon had written authoritatively on the origins of Sufism, which he regarded "as Arab as the Koran itself, in which it has its direct principles." 23

\footnotetext{
${ }^{18}$ Nile Green, Sufism: A Global History (Oxford: Wiley-Blackwell, 2012), 21.

${ }^{19}$ Hamka, Tasauf: Perkembangan dan Pemumiannya, 63.

20 Ibid., 60.

${ }^{21}$ Linda Sijbrand, "Orientalism and Sufism: An Overview," in Orientalism Revisited: Art, Land and Voyage, ed. Richard Netton (London: Routledge, 2013), 103.

22 See: Mona Abaza, Debates on Islam and Knowledge in Malaysia and Egypt (London: Routledge Curzon, 2002), 90; Georg Stauth, Politics and Cultures of Islamization in Southeast Asia (Bielefeld: Transcript Verlag, 2002), 187-228; and Sadiq Jalal Al-'Azm, "Orientalism and Orientalism in Reverse," in Forbidden Agendas: Intolerance and Defiance in the Middle East, ed. Jon Rothschild (London: Saqi, 1984), 349-76.

${ }^{23}$ René Guénon, Insights into Islamic Esoterism and Taoism, trans. Henry D. Fohr (New York: Sophia Perennis, 2004), 4 .
} 
But when did Sufism actually begin? To Hamka, Sufism could be traced to the lifetime of Prophet Muhammad and his companions in the seventh century. Elements of Sufistic doctrines can be found in the ascetic life of these early Muslims who were inspired by the Qur'an.

When read aloud by a person with a mesmerizing and beautiful voice and heard by those who are absorbed in the art of knowing God, the Qur'an initiates a person to be ready to become a Sufi ascetic, to be ready to abandon a life that is full of deception, to be ready to accept whatever little they receive with redha [contentment]. The message of the Qur'an seeped into Muhammad's soul, who was given the option of becoming a rich Prophet like Sulaiman, or a pauper such as the Prophet Job, but he chose to starve one day and be full on another ... Hence it is clear from my research that Sufism derived its roots from the Qur'an and the Hadith. ${ }^{24}$

Unlike the modernist reformers during Hamka's time who would rely only on authentic (shahih) Hadith as sources of reference on religious matters, Hamka accepted the use of weak (dhaif) Hadiths to elucidate his theory that Sufism began in earnest during the lifetime of the Prophet of Islam. This method of using weak Hadiths, according to Carl Ernst, was common among the Sufis, and it has brought them severe criticism from many Muslim scholars. ${ }^{25}$ Hamka, however, sees no real problem in using such Hadiths to encourage noble deeds. ${ }^{26}$ However, he admonished his readers that the same Hadith must not be used to justify acts of worship (ibadah). Hadiths that were maudhu (fabricated) are to be totally rejected and should not be considered at all in any discussions on the origins of Sufism and Sufi practices. ${ }^{27}$

Though inventive within the context of the Malay world, Hamka's interpretation of the origins of Sufism is barely original. A number of Muslim scholars based elsewhere have traced the beginnings of Sufism in almost the same manner as Hamka. Ibn Khaldun, for example, wrote in his Al-Muqaddimah:

Sufism is based on [the assumption] that the method of those people [who later on came to be called Sufis] had always been considered by the important early Muslims, the men around Muhammad and the men of the second generation, as well as those who came after them, as the path of truth and right guidance. ${ }^{28}$

Many scholars in the wake of Ibn Khaldun have also noted that it took a comparable amount of time for Sufism to be formalized and institutionalized as a distinct form of practice.

Hamka, however, brings that definition to another level by giving illustrative examples of Sufistic practices of the Prophet and his companions. He explicates the Prophet's piety and charitable acts even though he lived in poverty. Many Hadiths provide evidence of the Prophet's habit of waking up in the early hours of the morning to offer his prayers. The Prophet was recorded to have asked for forgiveness from

${ }^{24}$ Hamka, Tasauf: Perkembangan dan Pemurniannya, 207-8.

${ }^{25}$ Carl Ernst, Words of Ecstasy in Sufism (Albany: State University of New York, 1985), 118.

${ }^{26}$ Hamka, Hamka Membahas Kemusykilan Agama (Shah Alam: Pustaka Dini, 2009), 441-43.

${ }^{27}$ Hamka, Tasauf Moden (Kuala Lumpur: Pustaka Melayu Baru, 1970), xi.

${ }^{28}$ Ibn Khaldun, Al-Muqadimmah (Princeton: Princeton University Press, 1967), 76. 
Allah more than seventy times a day. He was patient in the face of extreme adversity. And, in one authentic Hadith, the Prophet emphasized that his followers should "be aloof from the world and Allah will love you. Be aloof from what the people possess and the people will love you." ${ }^{29}$ In Hamka's retrospective formulation, the Prophet was a Sufi par excellence even though the Prophet himself did not use the term "Sufi" to describe himself. To be a Sufi, therefore, is to follow the injunctions of the Qur'an and the Spiritual Way of the Prophet as documented in the Hadith.

The Prophet's Sufistic life was not unique to himself. Hamka stressed that, to understand the origins of Sufism, one must also factor in the ascetic lives of Muhammad's companions. Islam's first Caliph, Abu Bakar, had only one garment when he held office. Umar was so humble and austere that even his appointment as the Caliph did not make him forget his duties toward God. Even though endowed with a great deal of wealth, Uthman bin Affan was a spiritual man. Ali wore patched clothes throughout his life. The Prophet's other significant companions included those who stayed in the mosques and were deeply committed to the worship of God. They, Hamka wrote, "did not have families and wealth, and all of these did not steer them away from Allah. They were not disheartened because they received little of this world, and what pleased them was spiritual wealth because they were certain of victory in the days to come." 30 It is obvious here that Hamka drew heavily on the Sufi hagiographical tradition, which tended to embellish the Prophet's companions as the earliest and greatest examples of mystical piety in Islam. ${ }^{31}$

There are two implications that follow from Hamka's discussion of the origins of Sufism. By stressing that Sufism began with the Prophet himself and not the later generations, Hamka is indirectly dismissing the argument made by Muslim reformists and modernists that Sufism was a belated invention in Islamic history and an innovation within Islam. ${ }^{32}$ Sufism, to Hamka, was neither an invention nor an innovation. Its seeds were planted by God in his Prophet through the gradual revealing of the Quranic verses. The failure of reformists and modernists to see this point has made them unfairly dismissive of Sufism.

Hamka's ideas on the origins of Sufism had implications for the Sufis as well. By tracing Sufism back to the Prophet and his companions and asserting that true Sufism must be in line with Prophetic traditions, Hamka limits the interpretive possibilities of what Sufism was and should be. Claims by the Sufis that they were following a variant of Sufism other than what has been shown by the Prophet and his companions would be erroneous and deviant if measured against the yardstick of Hamka's interpretations. In other words, what Hamka indirectly sought to achieve by tracing Sufism back to the Prophet was to send a strong message to his Sufi readers that the early Muslims must be their primary source of reference and inspiration, rather than the practices, beliefs, and doctrines of the later Sufis and saints that may not necessarily be in line with orthodox Islam.

${ }^{29}$ An-Nawawi, 40 Hadith, trans. and commentary by Jamal Zarabozo (Denver: Al-Basheer Publications, 1999), 925.

${ }^{30}$ Hamka, Tasauf: Perkembangan dan Pemurniannya, 35.

${ }^{31}$ Mahmoud M. Ayoub, Islam: Faith and History (Oxford: Oneworld Publications, 2004), 121.

32 See, for example: Al-Munir, II, 8 (1912), 12. 


\section{The Parameters of Sufism}

Defining the parameters of what is and what is not Sufism lay at the center of Hamka's reorientation of that spiritual dimension of Islam. He saw the work of clearly demarcating what Sufism was and should be as necessary because there was a tendency among the Malays to confuse or conflate authentic Sufi practices with those of other pre-Islamic and supra-Islamic rituals. This was most palpable in Sumatra, where Hamka lived. Mystical beliefs were all too often intertwined with sorcery and magic. ${ }^{33}$

The exercise of setting the parameters of Sufism was, of course, not peculiar to Hamka or to scholars in the Malay World. William Chittick, for example, notes that Sufism has been subjected to so many different definitions and conceptualizations in different contexts and periods throughout Islamic history and society that a scholar must be precise about his or her definition of the term. ${ }^{34}$ This task was especially urgent in Hamka's eyes because, as Deliar Noer observed:

In Sufism, many of the traditionalists often fell into practices which were close to sjirk, associating God with beings and objects. They venerated keramat (shrines, graves of saints), gave offerings to spirits, held slametan or kenduri (feasts) as offerings, and used azimat or charms to protect themselves from evil genii or bad luck-which all in all resulted in the watering down, at least, of tauhid, the oneness of God. ${ }^{35}$

Hamka conceives of authentic Sufism (tasauf sejati) as a branch of the syariah (Islamic ethical and legal code) that aims to ...

... cleanse the soul, educate and refine the emotions, enliven the heart to be in constant prayer, and ennoble the character [while] suppressing greed and gluttony, battling excessive lust that goes beyond what is needed to achieve calmness. ${ }^{36}$

In another passage, Hamka extends his definition of Sufism as a path that Muslims took ...

... to seek the pleasure of Allah, so as not to be swayed by materialism, and through the passage of time, this deep spirituality became a means towards a more noble, powerful, and profound end. That is, to unveil the face of God, to witness the beauty of eternal life. But the aim to unveil the face of God would then become unsatisfying. Those who wished to rise above that, to reach an even higher station [maqam], in other words, to cease to exist [fanaa] and achieve union with God [ittihad], would do so through constant inner striving [mujahadah] and spiritual practices [riyadhah]. From this, there emerged a spiritual way of life

\footnotetext{
${ }^{33}$ See: Margaret J. Kartomi, Musical Joumeys in Sumatra (Illinois: University of Illinois Press, 2012), 323; and Mohammad Damami, Tasawuf Positif dalam Pemikiran Hamka (Yogyakarta: Fajar Pustaka Baru, 2000), 121.

${ }^{34}$ William Chittick, Faith and Practice of Islam: Three Thirteenth Century Sufi Texts (Albany: State University of New York, 1992), 173-76.

${ }^{35}$ Deliar Noer, The Modemist Muslim Movement in Indonesia, 1900-1942 (Kuala Lumpur: Oxford University Press, 1978), 300-301.

${ }^{36}$ Hamka, Tasauf Moden, 6.
} 
that is systematic of a religious philosophy that touches on matters pertaining to the soul. It became known as Sufism. ${ }^{37}$

The pure form of Sufism, Hamka adds, must be in line with laws governing rituals and daily conduct and not above and beyond them.

Hamka's ideas of Sufism as a branch of the syariah are derived primarily from the works and sayings of renowned Sufi mystics and scholars such as Junaid Al-Baghdadi (830-910), Abu Talib Al-Makki (died 996), Al-Qushayri (986-1072), Al-Ghazali (1058-1111), and Ibn Qayyim Al-Jauziyah (1292-1350) - all of whom he cites in his writings. He agrees with these mystics and scholars that following the syariah is the first step on the path to perfection, and as such offers more than by simply following Islamic law (fiqh).

Hamka then distinguishes the various branches of Sufism. The pristine form of Sufism, to Hamka, is concerned primarily with the refinement of character, or what has been termed by scholars as "Ethical Sufism." 38 Hamka held the view that the purpose of Sufism is to realize the highest of ethical standards (akhlaqul karimah). A person's character consists of two dimensions: the inner (batin) and the outer (zahir). By inner character, he means the training of the heart to constantly seek forgiveness from God, while beseeching for His mercy constantly. Training the inner character also involves thinking of things that would bring one closer to knowing the divine and reminding oneself of the eternal life in heaven or hell. All of these can be achieved through deep meditation, attentiveness to rituals, reciting chants, fasting, and searching for beneficial knowledge. Hamka uses the terms tasfiyah qulub (the cleansing of the heart), tazkiah al-nafs (self-purification), and riyadah al-nafs (self-discipline) to describe this process, while arguing that the heart is the seat of all diseases. ${ }^{39}$ The training of one's inner character is thus crucial because, through it, one may develop a strong relationship with Allah (habluminallah). In time, the Sufi votary would internalize the meanings of zuhud (sobriety), syukur (gratefulness), tawakkal (trust), khauf (fear), qanaah (contentment), ikhlas (sincerity), raja' (hopefulness), taqwa (piety), and tafakkur (contemplation). This would, in turn, shape one's behavior and enable that person to "change from a despicable character into a commendable one." 40

Hamka wrote several books, one of which is entitled Akhlaqul Karimah (referring to ethical standards and noble character), to elaborate on a person's outer character. ${ }^{4]} \mathrm{He}$ stressed that good character is one of the essential foundations not only of Sufism, but also of what it means to be a true Muslim. People with a noble character have adab (manners). They are sensitive to their surroundings, and are polite to everyone regardless of age, descent, or background. They refrain from saying or doing things that would be seen as immoral in the eyes of the public. But what is regarded as good character is also subject to change. In this, Hamka offers a dynamic view of the term

\footnotetext{
${ }^{37}$ Hamka, Tasauf: Perkembangan dan Pemumiannya, 20.

${ }^{38}$ Daphna Ephrat, Spiritual Wayfarers, Leaders in Piety: Sufis and the Dissemination of Islam in Medieval Palestine (Cambridge: Harvard University Press, 2008), 105. See also William Chittick and Sachiko Murata, The Vision of Islam (Cairo: American University in Cairo Press, 2006), 304.

${ }^{39}$ Hamka, Pandangan Hidup Muslim, 22-23.

"11 Hamka, Tasauf Moden, 15.

${ }^{41}$ Hamka, Akhlaqul Karimah (Jakarta: Pustaka Panjimas, 1992).
} 
akhlaqul karimah that depends on different contexts. For example, if society is heading toward adopting wrongful practices that are clearly contravening Islamic precepts, politeness and niceties must be dispensed with to put things right. The Sufis of the past, Hamka asserts, were noble in their character, but they were also foremost in rising up against the tide of disbelief and waywardness and were harsh when they needed to be. ${ }^{42}$

At the peak of one's ability to refine his or her inner and outer character is the eventual achievement of becoming al-Insan al-Kamil (lit., the perfect man). Here, Hamka draws heavily from the works of the Andalusian scholar and Sufi Ibn Al-Arabi, who first wrote about the doctrine of "the perfect man." 43 Agreeing with Ibn Arabi, Hamka maintained that very few persons, even among those who are steeped in Sufistic thought and practice, could actually achieve "perfection" in their lifetimes. When they do, such notable persons are inevitably held in high esteem. They are often described as waliyullah (the saints of Allah) and are honored by God. ${ }^{44}$

In addition to dealing with character and behavior, Sufism also has its devotional aspect. The devotional practices associated with Sufism, according to Hamka, were based on the practices of the Prophet and his companions. The Sufis systemized the disparate practices of these early Muslims so as to make them more accessible to ordinary Muslims, and to ease the path of recognizing the greatness of God and loving him wholeheartedly. ${ }^{45}$ The devotional dimension of Sufism includes two elements. Hamka prioritized adherence to the obligatory (fard) aspects of Islam over those that are supererogatory (nawafil). The Sufis, according to Hamka, stressed a strict implementation of the pillars of Islam that consisted of witnessing the oneness of Allah, praying five times daily, fasting, paying zakat (an annual payment to the needy to purify one's wealth), and making the pilgrimage to Mecca. Adherence to the pillars was to be followed by fadhail 'amal (supererogatory practices), such as charity, nightly prayers, and wirid dan zikir (remembering God, chanting). The highest form of devotion within Sufism is to achieve a state of khalwat (solitude), that is,

to be in a state of reflection, thinking, and retrospection with and about oneself. To avoid being in the company of many people, especially those who are aimless. Because too much companionship leads to too much talk that contravenes what is necessary. ${ }^{46}$

Sufis who are able to practice all of those devotions would eventually attain true happiness (kebahagiaan) in this life and the hereafter. They will become fully cognizant of the oneness of God and the oneness of all of his creation, and to them he will unveil the secrets of the unseen (kasyaf). ${ }^{47}$ The influence of the book Revelation of the Mystery (Kashf al-Mahjub), by the tenth-century Sufi master Ali bin Usman Hujwiri (990-

\footnotetext{
${ }^{42}$ Hamka, Pandangan Hidup Muslim, 191-92.

${ }^{43}$ William C. Chittick, Sufi Path of Knowledge: Ibn al-Àrabi Metaphysics of Imagination (Albany: State University of New York Press, 1989), 46.

${ }^{44}$ Hamka, Lembaga Hidup, 134.

${ }^{45}$ Hamka, Tasauf: Perkembangan dan Pemumiannya, 85.

46 Ibid., 99.

${ }^{47}$ Hamka, Pandangan Hidup Muslim, 30.
} 
1077), is noticeable here regarding Hamka's thinking about the unseen in Sufi thought. ${ }^{48}$

Hamka was, however, critical of a few offshoots of Sufism that he saw as destabilizing Muslim spirituality from within, such as philosophical Sufism (tawawuf filsofis). By philosophical Sufism, he was referring to "a form of philosophical inquiry that seeks to unveil the barrier between the outer and inner aspects of life. The search for what is hidden behind the screen." ${ }^{49}$ Persons such as Al-Suhrawardi al-Maqtul (1154-91), Abu Bakar Ibn al-Arabi (1076-1148), and Mansur Al-Hallaj (858-922) spearheaded such a strain within Sufism. To Hamka, these were later Sufis who were influenced by neo-Platonism, as well as by mystical ideas emanating from Persia, India, and the Christian world. Through their prose, poetry, and treatises, philosophical Sufis promoted the notion of Wahdatul Wujud, which connotes the unity between God and mankind. They also believed in the concept of Nur Muhammad, or Alhaqiqatul Muhammad, as the source of all deeds and knowledge. Above all, these Sufis held on to the idea that all religions are similar, differing only in name. These ideas were actually products of extreme reasoning and speculation, on the one hand, and being overwhelmed by feelings and mystical experience on the other. As a result, philosophical Sufis fell into the error of declaring that they were God themselves, as seen in the case of Al-Hallaj, or propounding theories about God and about the religions and religiosity that departed from the teachings of Prophet Muhammad. ${ }^{50}$

Although Hamka disagreed with the philosophical Sufis' ideas and methods of reasoning, he was sympathetic to their goals. The philosophical Sufis transcended the dissensions and endless arguments among scholars who were interested only in matters pertaining to laws and the superiority of their respective schools of thought. The philosophical Sufis sought to move away from those petty squabbles toward an emphasis on metaphysical issues, which, they felt, could bring Muslims closer to God. ${ }^{51}$ One can detect here Hamka's oblique criticism of the reformists and modernists whom he regarded as overly preoccupied with jurisprudential debates and differences. Still, if taken too far and permitted to become dominant in any given setting, Hamka felt that philosophical Sufism could bring its followers beyond the parameters of what Sufism really is, thereby weakening the Malay Muslims. Hamka cites the case of Hamzah Fansuri (died in 1590), a sixteenth-century Acehnese philosophical Sufi who, in Hamka's, estimation, "went too far."

He (Hamzah Fansuri) was an adherent of the teachings of al-Hallaj's Ana al-haqq [I am the truth]. His tariqa [sufi order] was called the "Wujudiyyah," promoting the unity between Creator and creature. The followers of this doctrine lost the spirit of struggle, which was in contrast with the spirit of jihad in Islam that was badly needed in Aceh at that time ... In the end Hamzah was killed because his doctrine was regarded as dangerous. His teachings, however, flourished in Java and become accepted by the followers of "Kawula Gusti." 52

\footnotetext{
${ }^{48}$ Ali bin Usman Hujwiri, Revelation of the Unseen, trans. R. A. Nicholson (New York: Pir Press, 1999).

49 Hamka, Tasauf: Perkembangan dan Pemurniannya, 137.

50 Ibid., 150.

51 Ibid., 110-11.

${ }^{52}$ Hamka, Sejarah Umat Islam, 914.
} 
Hamka's sympathy for philosophical Sufism is, however, not evident in his approach to extremist Sufis and popular Sufism. Extremist Sufis (Sufi yang ta'asub) were those Sufis who submitted their lives totally to their syaikhs (masters). They called themselves murids (novices) who held the syaikhs as intercessors for prayers, as guides in spiritual matters, and as avenues by which the greatness and love of God could be experienced. The murids, therefore, lose their selves completely in their syaikhs. This was a train of thought that Hamka totally opposed in many of his writings on Sufism and his exegesis of the Qur'an. He advocated the use of reason on the part of Sufis and for them to avoid being driven by emotions to the extent that the syaikhs would be revered beyond what is acceptable in Islam. ${ }^{53}$

Hamka further argues that the Prophet enjoined Muslims to develop a direct connection with God without any intermediaries. The terms wasilah (means of approach) and rabithah (relationship forged with a spiritual guide) have been wrongly understood by the Sufis to represent submitting one's life to a person in the form of the syaikh or a saint, either dead or alive. In Indonesia, the inordinate love for syaikhs and saints gave rise to the worship of graves and tombs, to the extent that Hamka described the Malay World as having a "hub of graveyards" that a Muslim would frequently visit to pray for the dead and ask for anything he or she wished. ${ }^{54}$ Alternatively, Hamka stressed that the acceptable form of wasilah is to seek help from a learned or pious person regarding how to pray for oneself. In Hamka's rendering of Sufism, syaikhs are merely guides to be sought after if one requires their assistance, but they are not to be revered beyond what has been stipulated in Islam. In making such statements about the status of the syaikhs in Sufism and regarding them as intermediaries, Hamka's ideas bear striking parallels to those of Ibn Taymiyyah. ${ }^{55}$

Popular Sufism, in turn, refers to the kebatinan (the search for inner truth) movements in Indonesia. ${ }^{56}$ These movements were a product of Javanese mysticism, which, with the coming of Islam, incorporated various ideas of Sufism into their beliefs and practices. Popular Sufism became important as early as the 1930s and flowered during the time of the New Order government, from the 1960s to the 1980s. Some of these kebatinan have gone to the extent of receiving revelation from God (wahyu) above and beyond what has already been revealed to the Prophet Muhammad. ${ }^{57}$ Hamka saw this as a symptom of the superficial understanding of Islam

${ }^{53}$ Wan Sabri Wan Yusof, "Hamka's Tafsir Al-Azhar: Quranic Exegesis as a Mirror of Social Change" (PhD dissertation, Temple University, 1997), 209.

${ }^{54}$ See: Hamka, Pelajaran Agama Islam (Kelantan: Pustaka Aman Press, 1967), 69-70; and Hamka, Mengembalikan Tasawuf Ke Pangkalnya (Jakarta: Pustaka Panjimas, 1973), 40-41.

${ }_{55}$ See: Jon Hoover, Ibn Taymiyya's Theodicy of Perpetual Optimism (Leiden: Brill, 2007), 206; and Hamka, Tafsir al-Azhar, Vol. 3, 1723.

56 They were also known as kejawen (Javanism), kejiwaan (inner soul), and aliran kepercayaan (streams of thought). A detailed and remarkable study on this is found in: Suwardi Endaswara, Mistik Kejawen: Sinkrestime, Simbolisme dan Sufisme dalam Budaya Spiritual Jawa (Yogyakarta: Penerbit Narasi, 2006); and Paul R. Stange, "Legitimate Mysticism in Indonesia," Review of Indonesian and Malaysian Affairs 22, 2 (1986): 76-117.

${ }^{57}$ See: Julia D. Howell, "Muslims, the New Age and Marginal Religions in Indonesia: Changing Meanings of Religious Pluralism," Social Compass 52, 4 (2005): 472-93; and Bianca J. Smith, "When Wahyu Comes through Women: Female Spiritual Authority and Divine Revelation in Mystical Groups and Pesantren Sufi Orders," in Gender and Power in Indonesian Islam: Leaders, Feminists, Sufis and Pesantren Selves, ed. Bianca J. Smith and Mark Woodward (London: Routledge, 2014), 87-88. 
among many Javanese. He also was aware that the kebatinan groups were attracting people who had been alienated from Islam by the reformists, and also those interested in a modern framing of spirituality. ${ }^{58}$

Unlike many modernist thinkers, such as H. M. Rajidi and H. A. Mukhti Ali, who launched an all-out effort to discredit the kebatinan movements, Hamka called for a mild and intellectually driven approach. He explained that kebatinan movements have persisted due to a host of factors, including the Dutch divide and rule policies in Indonesia, Javanese resistance to accepting orthodox Islam, and the schemes of many shamans who employed a combination of magic, trickery, and Islamic idioms to win the masses over to their own selfish ends. ${ }^{59}$ Kebatinan movements cannot be changed overnight or through sharp criticisms; instead, they should be approached in a respectful manner, and dialogues should be held so as to realize the aim of "Reconstituting Sufism to Its Original Form" (Mengembalikan Tasauf kepada Pangkalnya), which was the title of another one of Hamka's books. ${ }^{60}$

Hamka held Sufi brotherhoods, tariqas, in high regard as long as they adhered to the teachings of the Qur'an and the Sunnah. To be sure, Sufi orders were excellent platforms for the preaching of Islam ( $\left.d a^{\prime} w a h\right)$. The Sufis, Hamka stressed, also "established the Tariqa movements with the intent of training the self to live moderately and to focus their aims toward seeking Allah so as to free oneself from the lure of worldly wealth." ${ }^{61}$ Hamka pays tribute to the Sanusiyyah tariqa in Libya for its role in resisting colonial rule and reforming society for many centuries, and he cites the contributions of the Tijaniyyah movement in the spread of Islam in North Africa. The tariqas, to Hamka, maintained the pristine form of Sufism. Hamka, however, also highlighted the waywardness of those tariqas that fused Islamic teachings with unIslamic practices, folk beliefs, and superstitions. This was evidenced in the Maulawiyah (or Mevlevi) that incorporate dances and whirling in their devotional practices. Another case in point is the Rifai'iyah Sufi order in Aceh and Banten, which taught its followers to believe that they were invulnerable. These cults existed in parts of the Malay World until the 1980s, but, in Hamka's eyes, "none of these are acceptable in Islamic missionary work, for they are merely entertainment." 62 Drawing upon the works of the medieval scholar Al-Ghazali, Hamka states that the study and practice of Sufism through the tariqas must come after achieving a deep understanding of Tauhid (the oneness of God) and the laws of Islam as enshrined in the syariah, "so that we are not swayed by our emotions, outside the bounds of knowledge."63

Still, Hamka maintained that belonging to a Sufi order was not a necessary precondition for anyone who wished to tread the spiritual path. Hamka advocated the idea of tawawuf tanpa tarekat (Sufism without tariqa), a version of Sufism that is unprecedented in the history of Sufism in the Malay World. Julia Howell rightly describes this version of Sufism as an enabling factor for "modern Muslims to

\footnotetext{
${ }^{58}$ Hamka, Perkembangan Kebatinan di Indonesia (Jakarta: Bulan Bintang, 1971).

${ }^{59}$ Harry Benda, "Christiaan Snouck Hurgronje and the Foundations of Dutch Islamic Policy in Indonesia," The Joumal of Modem History 30, 4 (1958): 338-47.

${ }^{60}$ Hamka, Mengembalikan Tasawuf Ke Pangkahny.

${ }^{61}$ Hamka, Prinsip dan Kebijaksanaan Da'wah Islam (Kuala Lumpur: Pustaka Melayu Baru, 1981), 210.

62 Ibid., 222.

63 Ibid. See also Hamka, Hamka Membahas Kemusykilan Agama, 548.
} 
cultivate a sense of closeness to God, and possibly even experience a lifting of the veils of earthly perception, without, however, getting involved in a Sufi order or using the Sufis' meditative rituals such as collective zikir (repetitive recitations of litanies)."64 I would go even further and argue that Hamka's promotion of Sufism without tariqa has democratized the practice of Sufism in the Malay World. One of the impacts of Hamka's writings was a decline in the reliance on the syaikhs of Sufi orders as mediums and guides in the spiritual life of ordinary Muslims.

\section{Tasawuf as a Constructive Force in the Malay World}

From the discussion above, it is clear that Hamka acknowledged the importance of Sufism within Islam. He goes even further to maintain that Sufism and Sufis have been among the crucial agents in the making and remaking of Muslim societies and civilization. They must and will continue to do so by "inculcating the spirit of determination in every task at hand. Deep spirituality brings forth dynamism and passion, giving rise to sincerity and honesty." 65 It follows from this that it is almost unthinkable for Muslims to progress without Sufism as a frame of reference. But the task of reorienting Sufism in the Malay World does not stop here. For Sufism to persist as a constructive force in the lives of Muslims, Hamka proposed a number of ideational reforms. It is here that we see a part of Hamka that was akin to the reformists and modernists of his time. To Hamka, the point was not only to document what true Sufism is, but also to change the present state of Islamic mysticism to make it congruent with modernity.

First, emphasis must be placed on the positive interpretations of Sufism (tasawuf positif) as opposed to the negative interpretations of Sufism (tawawuf negatif), which must be eradicated. ${ }^{66}$ Hamka directs his attention to a number of key concepts in Sufi cosmology that have been wrongly conceptualized by Muslims. Zuhud has been expressed as a retreat from worldly life by secluding oneself from society, but Hamka regarded such an understanding of zuhud as selfish and egoistic. ${ }^{67} \mathrm{He}$ discusses this at length and offers a reinterpretation of the concept:

There are so many Islamic teachings that are still written and read till today but are least understood because of the imbalance in knowledge. For example, the idea of Zuhud. When the religious spirit fades, Zuhud is wrongly understood. It signifies revulsion towards worldly life, revulsion towards wealth, revulsion towards status. Thus grew a self-deceiving predisposition that is an upshot of misconceptions. The world therefore escapes from one's grasp because one is taught to detest it. But this world is a place to sow, and the hereafter a place to reap. Detesting wealth leads to poverty, so much so that even a mosque could

${ }_{64}$ Julia D. Howell, "Revitalised Sufism and the New Piety Movements in Islamic Southeast Asia," in Routledge Handbook of Religions in Asia, ed. Bryan S. Turner and Oscar Salemink (London: Routledge, 2015), 282.

${ }^{65}$ Hamka, Pelajaran Agama Islam, 33-34.

${ }^{66}$ A detailed analysis of Hamka's tasawuf positif is found in: Mohammad Damami, Tasawuf Positif dalam Pemikiran Hamka (Jakarta: Fajar Pustaka Baru, 2000).

${ }^{67}$ Hamka, Said Djamaluddin Al-Afghany: Pelopor Kebangkitan Muslimin (Jakarta: Penerbit Bulan Bintang, 1970), 59 . 
not be built ... We accuse the West of being materialistic, and the East we call, Idealist. But our pure teachings enjoin the seeking of as much wealth as we can so that the commandments of Allah can be upheld. [We are] enjoined to struggle and uphold Allah's path, foremost with wealth, then with our lives. Muslims are commanded to work hard so they can amass great wealth, so as to assist society with the wealth that they yield. ${ }^{68}$

For Hamka, the proper interpretation of zuhud is summarized by the following words of Imam Ahmad bin Hanbal: "Seeking that which is permitted but to a degree that is necessary, without being excessive." 69

Two other concepts, which have been wrongly interpreted by Sufis in the Malay World, according to Hamka, were qanaah (contentment) and tawakkal (trust in God). These two terms have been used interchangeably by some Sufis to mean that Muslims should accept their fates, to be mediocre at work, and to leave it to God to change their destinies. Hamka was totally opposed to such misunderstandings of those terms, believing that these misconceptions encouraged the culture of laziness among many Muslims. For Sufism to be a positive and empowering factor in Muslim life, Hamka redefined the word qanaah as the state of feeling assured of whatever one has achieved. Similarly, tawakkal is not about leaving everything to God, but means to struggle hard before leaving the outcomes of one's efforts to the mercy of the divine. Hamka derived this from the famous Hadith of the Prophet who was reported to have said: "Tie the camel first and then put your trust in Allah."70

The second ideational reform that Hamka called for was the modernization of Sufism. He used the term tasawuf moden (modern Sufism), in contrast to tasawuf tradisional (traditional Sufism). Tasawuf tradisional basically means a form of Islamic spirituality that is blemished with innovations, superstition, and the worship of anyone other than God. The practitioners of tasawuf tradisional were also averse to changes around them while insisting that to be a Sufi was to live like the Sufis of the past. Modern Muslims were shying away from Sufism because of this and Hamka saw this as tragic. The educated class of Muslims in particular, Hamka wrote, "feel that to be spiritual is to be old-fashioned."7l Hamka is not wrong in making this argument, for studies have shown that Sufism in the Malay World suffered from a brief decline before World War Two and in the immediate post-war period. ${ }^{72}$

Tasawuf moden is thus sensitive to the needs of the emerging generation, forwardlooking, and dynamic. It is centered around the creation of spiritually conscious, morally upright, and socially connected Muslims who keep up with the demands of modern life. The main goal of tasawuf moden is the realization of total happiness, both in this life and the hereafter. In this regard, Hamka is clearly influenced by

\footnotetext{
${ }^{68}$ Hamka, Empat Bulan di Amerika, Djilid 2 (Djakarta: Tintamas, 1954), 65.

${ }^{69}$ Hamka, Prinsip dan Kebijaksanaan Da'wah Islam, 222. See also: Hamka, Hamka Membahas Kemusykilan Agama, 548.

${ }^{70}$ Hamka, Tasauf Moden, 279.

${ }^{71}$ Hamka, Filsafat Ketuhanan (Melaka: Toko Buku Abbas Bandong, 1967), 21.

${ }^{72}$ See: Mark Sedgwick, Saints and Sons: The Remaking of the Rashidi Ahmadi Sufi Order (Leiden: Brill, 2005), 183; and Julia Day Howell, "Modulations of Active Piety: Professors and Televangelists as Promoters of Indonesian 'Sufisme,'" in Expressing Islam: Religious Life and Politics in Indonesia, ed. Greg Fealy and Sally White (Singapore: ISEAS, 2008), 41.
} 
Al-Ghazali's book The Alchemy of Happiness. ${ }^{73}$ He divides happiness that could be gained through the practice of tasawuf moden into five parts-happiness in terms of wealth, happiness through kinship relations, happiness gained from social status, happiness from one's lineage and background, happiness in the form of bodily health, and happiness obtained from following the path of God. Such happiness would serve as the catalyst and inspiration for Muslims to continuously progress (kemajuan) in an ever-changing world. ${ }^{74}$ This progress would not erode spirituality, but, rather, enhance it further.

Hamka also agitated for the cleansing of Sufism from myths and legends (tahyul dan dongengan) and the embrace of reason and intellectualism (akal dan keilmuan). Sufism in the Malay World has been led by ...

... syaikhs of tariqas with their special flags; filled with superstition and wayward beliefs. And not least are the many layers of trickery [that come with them]. Not least also are the shamans, the soothsayers, the sorcerers, and the fortune tellers. ${ }^{75}$

Rulers and Sufis kept these myths and legends alive to ensure the blind obedience (taqlid) of the masses. These myths and legends often contradict the laws of life and the Qur'an. Examples of such stories include the conversion of kings by the Prophet Muhammad himself, the figure of Alexander that was purported to be Iskandar Zulkarnain, and the miraculous feats of the nine saints of Java. ${ }^{76}$

True Sufism departs from the machinations of the "corruptors of Sufism."77 Hamka exhorts his readers to use their God-given power of reasoning (kekuatan akal) in charting a spiritual life and battling their inner desires. The use of critical reasoning does not, however, entail the abandonment of imagination, esotericism, and mysticism. In Hamka's words, "Sufism does not reject knowledge, true Sufism does not reject reality." ${ }^{78} \mathrm{He}$ furthers this point in Tasauf Moden by stressing that "to live, use your mind. The mind is the motor of life. A healthy reasoning moves between the mind and the desires. The mind is at the top, desires are at the bottom, and reasoning is at the centre."79 Put differently, to be a modern Sufi is to strike a balance between the intellect, the emotions, and the will to love God and his creation.

Hamka also questioned the dichotomizing of spirituality from secular life. This dichotomy was made possible by Muslims who were impressed by the ideologies of secularism promoted by the West. Hamka gave the examples of Kamal Atartuk (in Turkey) and Syeikh Abdul Raziq (in Egypt), both of whom divorced politics from religion and spirituality from public life, hence falling into the fallacy of thinking about life in dualistic terms. ${ }^{80}$ As an alternative, Hamka called for the coming together

\footnotetext{
${ }^{73}$ Al-Ghazali, The Alchemy of Happiness, trans. Claud Field (Lahore: Sh. Muhammad Ashraf, 1987).

${ }^{74}$ Hamka, Tasauf Moden, 130-33.

75 Hamka, Pelajaran Agama Islam, 33.

${ }^{76}$ Hamka, Dari Perbendaharaan Lama (Kuala Lumpur: Penerbit Pustaka Antara, 1981), $202-43$.

${ }^{77}$ Hamka, Falsafah Hidup (Kuala Lumpur: Pustaka Aman Press, 1982), 50.

78 Ibid., 54.

${ }^{79}$ Hamka, Tasauf Moden, 145.

${ }^{80}$ Hamka, Pengajian Islam (Kelantan: Pustaka Aman Press, 1977), 155.
} 
of the spiritual and the secular, with Sufism as a medium. "Let us be Sufis in confronting the demands of everyday life, even in commerce, even in politics, Sufi in business, Sufi in nurturing and teaching." ${ }^{1}$

\section{Hamka's Ideas, Ideals, and Influence on Sufism in the Malay World}

A cursory survey will show that the discourses about Sufism in the Malay World today are saturated with Hamka's thought. His concepts of Tasawuf Positif and Tasawuf Moden (or Tasauf Moderen) have inspired several monographs on the subject. ${ }^{82} \mathrm{His}$ books on Sufism have sold by the thousands and have been reprinted more than a dozen times by scores of publishers in Singapore, Malaysia, and Indonesia. The celebrated Indonesian intellectual Nurcholish Madjid underlined this point by stating that it has become almost impossible to begin or end any discussion of Sufism in Indonesia without a passing reference to Hamka's extensive oeuvre. ${ }^{83}$ Hamka's project of reorienting Sufism as a style of thought and a mode of piety that ought to be in line with the syariah and purified from the many external influences has also gained him many followers who now adopt a universalist, inclusive, individualized, deritualized, and non-sectarian form of Islamic spirituality. So persuasive has Hamka been that many members of the Muhammadiyah have become more open to Sufism and Sufis in Indonesia, and as a result have taken a more reformist and modernist path in their practice of Islam. ${ }^{84}$

In assessing the long shadow that Hamka has cast over Sufism in the Malay World, one wonders what it is that makes his works so alluring. The key to explaining Hamka's popularity may be found in the structure of his writings. Hamka was deeply aware of his audience, and wrote primarily for adherents of Sufism and their enemies, and without forgetting those readers who may have been exposed to either of those groups. As a result, Hamka's works on Sufism became accessible to all within an increasingly diverse and polarizing Muslim society, just as he touched on issues that affected everyone. Indeed, if it is to be accepted that Islam in the Malay World is characterized by its ability to syncretize many different strands of thought into a unique version of a cosmopolitan and inclusive Islam, Hamka may be seen as the offspring of that tradition.

\footnotetext{
${ }^{81}$ Hamka, Pandangan Hidup Muslim, 52.

82 See: Ahmad Najib Burhani, ed., Manusia Menimba Allah: Renungan Tasawwuf Positif (Jakarta: Penerbit Hikmah, 2002); C. Ramli Bihar Anwar, Bertasawuf Tanpa Tarekat: Aura Tasawuf Positif (Jakarta: Penerbit IIMan, 2002); and Sudirman Tebba, Tasawuf positif: Manfaat Tasawuf Dalam Kehidupan Sehari-Hari (Jakarta: Pustaka irVan, 2008).

${ }^{83}$ Nurcholish Madjid, Tradisi Islam: Peran dan Fungsinya dalam Pembangunan di Indonesia (Jakarata: Paramadina, 1997), 123-32.

${ }^{84}$ Martin van Bruinessen, "Controversies and Polemics Involving the Sufi Orders in Twentieth-Century Indonesia," in Islamic Mysticism Contested: Thirteen Centuries of Controversies and Polemics, ed. Frederick de Jong and Bernd Radtke (Leiden: Brill, 1999), 729.
} 